\title{
REDESENHANDO A FUNDAMENTALIDADE DO DIREITO PROCESSUAL DO TRABALHO: PROPOSTAS INTERPRETATIVAS A PARTIR DO NOVO CÓDIGO DE PROCESSO CIVIL
}

\section{EL REDISEÑO DE LA FUNDAMENTALIDAD DEL DERECHO PROCESAL DEL TRABAJO: PROPUESTAS INTERPRETATIVAS DEL NUEVO CÓDIGO DE PROCEDIMIENTO CIVIL}

\author{
${ }^{1}$ Luciana Costa Poli \\ ${ }^{2}$ Bruno Ferraz Hazan
}

\begin{abstract}
RESUMO
Propõe-se, partindo das tendências hermenêuticas pós-positivistas, analisar algumas novas perspectivas interpretativas do Direito Processual do Trabalho, em especial a releitura do conceito de subsidiariedade, novamente em voga a partir da publicação da Lei n. 13.105

$/ 2015$ (novo Código de Processo Civil), para a aplicação do Direito Processual Comum não só diante de lacunas normativas, mas também diante de lacunas ontológicas e axiológicas. A partir disso, desenha-se um novo caminho para que o Direito Processual do Trabalho possa enfrentar a ausência de efetividade desencadeada por uma fase de execução que não reflete suas premissas inerentes de fundamentalidade e celeridade.
\end{abstract}

Palavras-chave: Princípio da efetividade, Princípio da celeridade, Princípio da subsidiariedade, Sincretismo processual

\begin{abstract}
Se analizarán, sobre la base de las tendencias hermenéutica post-positivistas, algunas nuevas perspectivas interpretativas del Derecho Procesal del Trabajo, como la reinterpretación del concepto de subsidiariedad, de nuevo en boga desde la publicación de la Ley 13.105/2015 (el nuevo Código Procesal Civil), para la aplicación del Derecho Procesal Común no sólo en lagunas normativas, sino también en las lagunas ontológicas y axiológicas. A partir de esto, se propone una nueva manera para que el Derecho Procesal del Trabajo pueda enfrentar la falta de efectividad provocada por una fase de ejecución que no refleja su suposiciones inherentes de fundamentalidad y celeridad.
\end{abstract}

Keywords: Principio de la efectividad, Principio de la celeridad, Reglas de subsidiariedad, Sincretismo processual

\footnotetext{
${ }^{1}$ Pós doutora pela Universidade Estadual de São Paulo, UNESP - SP, (Brasil).Doutora em Direito e professora pela Pontifícia Universidade Católica, PUCMINAS - MG, (Brasil). E-mail: lucostapoli@ yahoo.com.br

${ }^{2}$ Doutorando em Direito pela Pontifícia Universidade Católica, PUCMINAS - MG, (Brasil). Professor na Escola Superior Dom Helder Câmara, EDSHC - MG, (Brasil). E-mail : bruno.hazan@ gmail.com
} 


\section{INTRODUÇÃO}

Não se pode cogitar em normas jurídicas sem a existência concorrente de meios eficazes para sua efetivação - tutela jurisdicional. De fato, os princípios não bastam sem que haja instrumentos eficazes para sua implementação. A partir disso, constrói-se a ideia de fundamentalidade do direito processual - consubstanciado primordialmente em sua instrumentalidade.

Ocorre que a fundamentalidade do direito processual deve ser acompanhada de meios que tornem a tutela jurisdicional ampla, justa e efetiva. O processo não basta. O que se deve buscar é um direito processual célere e efetivo, especialmente quando a norma processual em destaque é tida como o meio para se efetivar direitos igualmente fundamentais e sociais - que é o caso do Direito Processual do Trabalho.

Perpassando pela lógica de fundamentalidade do Direito Processual do Trabalho, o presente estudo investiga algumas possibilidades de efetivação tutela jurisdicional trabalhista, em especial a partir do Princípio da Subsidiariedade e seus desdobramentos na teoria das lacunas normativas. Destaca-se, com isso, a utilização irrestrita dos meios executivos disponibilizados ao juiz em todas as fases do processo (tutelas de urgência e de evidência) e a construção de um Direito Processual do Trabalho sincrético - tudo isso espelhado nas reformas de 1994, 2005 e 2006 do antigo Código de Processo Civil - e, agora, incorporadas no novo Código de Processo Civil (Lei n.13.105/2015).

Ao final, partindo da reafirmação do Poder Judiciário na efetivação do Direito, pretendese demonstrar que o direito a uma razoável duração do processo (inserido no eixo fundamental de garantias individuais) exige a busca por um sistema hermenêutico aberto e integrativo, não mais pautado nas clássicas barreiras da interpretação puramente gramatical. 


\section{A FUNDAMENTALIDADE DO DIREITO PROCESSUAL DO TRABALHO}

Não se pode falar em efetividade de um direito sem os devidos meios processuais para exercê-lo. Seria incoerente cogitar que apenas os direitos materiais possibilitariam condições plenas para uma efetiva organização humana. A simples existência de uma norma (de direito material ou substancial) não a torna efetiva. São necessários meios capazes de garantir sua concretização ${ }^{1}$.

Segundo Reale (2012, p. 594 e 599), “o Direito é uma realização de fins úteis e necessários à vida, ou por ela reclamados [...] quando reputamos algo valioso e nos orientamos em seu sentido, o valioso apresenta-se como fim que determina como deve ser o nosso comportamento".

A concepção do homem de que o direito consiste em um dever-ser demonstra que a sociedade percebeu que algumas concepções fundamentais devem ser extraídas (pelo menos em parte) do seu próprio indivíduo e direcionadas a um terceiro (neste caso, o Estado) para que, fiscalizando-as, garanta que condutas moralmente almejadas sejam resguardas para todos. Assim, mesmo em meio a tantas desvirtudes, o homem é capaz de conviver e se organizar em sociedade.

Com isso, transparece o caráter fundamental das normas que compõe a estrutura de nossa sociedade e, também, do direito processual. Porém, sua fundamentalidade não pode ser extraída apenas pelo fato de estar inserido constitucionalmente no capítulo dos direitos e garantias fundamentais - sentido formal ${ }^{2}$. Mais que isso! Sua fundamentalidade deve ser percebida em razão de sua instrumentalidade - sentido material.

Assim, não se pode cogitar em normas sem a existência concorrente de meios eficazes para sua efetivação (tendência esta ressaltada pela superação do positivismo jurídico a partir, especialmente, das Constituições promulgadas após a segunda guerra mundial). De fato, os princípios não bastam sem que haja instrumentos eficazes para sua implementação.

\footnotetext{
1 Muitas vezes, nem mesmo assim as normas são cumpridas, pois dependem de uma série de fatores

2 Marinoni (2008, p. 68) explica que "os direitos fundamentais podem ser vistos nos sentidos material e formal. Nesse último sentido, pensa-se nos direitos fundamentais catalogados sob o Título II da CF [...]. Porém, admite-se a existência de direitos fundamentais não previstos nesse Título. Tais direitos seriam fundamentais porque repercutem sobre a estrutura básica do Estado e da sociedade, quando se diz que possuem uma fundamentalidade material".
} 
Pode-se afirmar, com isso, que tão essencial como o direito material é o direito processual que deve, com aquele, concorrer na busca da efetivação de todos os direitos. Daí seu caráter de instrumento:

\begin{abstract}
Como o direito processual não se propõe a reger diretamente as relações das pessoas ou grupos na vida comum nem atribuir-lhes bens da vida ou definir-lhes ou sancionarlhes as condutas - mas a regular a vida do processo - segue-se que as normas processuais têm caráter instrumental perante as de direito material [...]. O caráter instrumental das normas processuais qualifica-as como secundárias (DINAMARCO, 2001a, p. 68).
\end{abstract}

É bom destacar que seu caráter instrumental não pode ser confundido como subsidiário em relação às normas de direito material, uma vez que para a efetivação destas, aquelas são essenciais. Daí se cogitar em uma função concorrente e não subordinada. Segundo Gonçalves (1992, p. 49-50), ambas as normas "disciplinam condutas, inserem-se no mesmo ordenamento jurídico e se complementam mutuamente. A distinção entre elas se mantém pelo conteúdo que comportam, e não pela referibilidade a qualquer hierarquia”. Neste mesmo sentido:

[...] o direito processual é constituído [...] de um sistema de normas que disciplinam mais ou menos complexos mecanismos (processuais) destinados a garantir que a norma substancial seja atuada na hipótese de falta de realização espontânea da parte de quem é obrigado. [...] Afirmar a diversidade entre direito substancial e direito processual, e a instrumentalidade do segundo em relação ao primeiro, não significa absolutamente uma autonomia (no sentido de indiferença) entre os dois complexos normativos [...] o direito processual não pode existir sem o direito substancial (indisponibilidade do direito substancial), igualmente - convém acrescentar - o direito substancial não pode existir sem o direito processual. Apesar da diversidade, existe uma estreita interdependência (isto é, recíproca dependência) entre direito substancial e direito processual (PROTO PISANI,2006, p. 10-11).

Nessa perspectiva, seria ilógico perceber o processo como um meio de efetivação dos direitos materiais, mas, no entanto, não inserir a questão de sua efetividade como um tema fundamental! Assim, sem sombra de dúvidas, o direito processual é um direito fundamental tanto em sua dimensão objetiva como em sua dimensão subjetiva ${ }^{3}-$, pois, sem o processo, os direitos materiais lesados (ausência de cumprimento espontâneo) não se efetivariam:

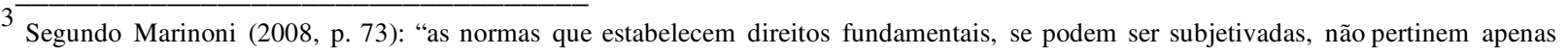
ao sujeito, mas sim a todos aqueles que fazem parte da sociedade. Ou seja, os direitos fundamentais não apenas garantem direitos subjetivos, mas também fundam princípios objetivos orientadores do ordenamento jurídico".
}

Tal direito não poderia deixar de ser pensado como fundamental, uma vez que o direito 
à prestação jurisdicional efetiva é decorrência da própria existência dos direitos e, assim, a contrapartida da proibição da autotutela. O direito à prestação jurisdicional é fundamental para a própria efetividade dos direitos, uma vez que esses últimos, diante das situações de ameaça ou agressão, sempre restam na dependência de sua plena realização. Não é por outro motivo que o direito à prestação jurisdicional efetiva já foi proclamado como o mais importante dos direitos, exatamente por constituir o direito a fazer valer os próprios direitos (MARINONI, 2004, p. 184-185).

Portanto, a tutela jurisdicional é fundamental como meio para concretização das normas $^{4}$. Essencial, então, pensar-se não apenas em uma tutela jurisdicional, mas em uma tutela jurisdicional ampla (aplicável a todos, em nível de facilidade de acesso e de simplicidade dos atos - acesso à justiça), justa (com garantias de contraditório e ampla defesa - modo) e efetiva (célere e com meios adequados para sua execução, em especial na concretização de uma tutela específica - resultado) (BARBOSA MOREIRA, 1984a, p. 27-28).

\title{
3 A EFETIVIDADE DO DIREITO PROCESSUAL: NOVOS RUMOS
}

A partir da década 70 (no mundo ocidental) deu-se início uma série de reformas processuais com a tendência de efetivação da tutela jurisdicional, em especial no quesito acesso à justiça, como claro reflexo processual do pós-positivismo, conforme nos explica Pimenta (2012, p.459):

\begin{abstract}
A partir da década de setenta do século XX, generalizou-se em todos os países do mundo ocidental a ideia de que seus sistemas judiciários estavam em crise, sendo indispensável sua profunda a imediata reforma para proporcionar a todos os jurisdicionados o pleno e efetivo acesso à justiça [...]. [...] $\mathrm{O}$ generoso movimento mundial de ampliação do acesso à justiça (reflexo, no plano processual, da superação do positivismo jurídico pelo denominado pós-positivismo [...]) passou a propugnar, em síntese, pela construção, em cada ordenamento jurídico nacional, um novo sistema processual, capaz de proporcionar a todos os jurisdicionados, sem distinções infundadas, a possibilidade de obter, do Estado-Juiz, uma tutela jurisdicional efetiva, célere a adequada de seus direitos materiais $[\ldots]$.
\end{abstract}

\footnotetext{
4 No caso do Direito do Trabalho tal aspecto se mostra mais relevante, tendo-se em vista que as normas trabalhistas foram objetivamente içadas ao nível de fundamentais pelo legislador constituinte (artigos $7^{\circ}, 8^{\circ}$ e $9^{\circ}$ da CR/88). Daí, não é exagero dizer que o Direito Processual do Trabalho se coloca em um nível de fundamentalidade ainda maior, já que as normas que pretende efetivar são essencialmente e objetivamente fundamentais.
} 
O mesmo autor destaca que, não obstante nossa Constituição da Republica de 1988 ter sido promulgada com tais propósitos, a reforma do judiciário (Emenda Constitucional $\mathrm{n}$. 45/2004) é que aproximou tais anseios à realidade, reforçando e resguardando a efetividade e a democratização do processo - ampliando-se o acesso à justiça e criando transparência e controle democrático da atividade jurisdicional (PIMENTA, 2012, p. 460).

Portanto, uma tutela jurisdicional efetiva, do ponto de vista constitucional, parece ser aquela que tende a implementar a celeridade, a adequação e a efetividade, não obstante a Emenda Constitucional n. 45/2004 ter dado prioridade à celeridade ${ }^{5}$.

Percebe-se que a celeridade não deve ser encarada apenas no ponto de vista de uma tutela de urgência, mas também do ponto de vista da própria estrutura temporal do processo. Segundo Marinoni (2004, p. 183): “O direito à tempestividade não só tem a ver com a tutela antecipatória, como também com a compreensão da duração do processo de acordo com o uso racional do tempo processual por parte do réu e do juiz".

A morosidade e, com isso, a pouca efetividade do Poder Judiciário, tem como causa maior um tipo específico de litigiosidade ${ }^{6}$ : a litigiosidade em massa (ou de alta intensidade), pela qual são ajuizadas ações repetitivas com questões comuns: é o caso dos litigantes habituais.

Portanto, o baixo índice de cumprimentos espontâneos (cultura do inadimplemento) constitui um dos maiores óbices para uma tutela jurisdicional trabalhista efetiva. É o que se denomina síndrome do descumprimento das obrigações:

O verdadeiro problema, pura e simplesmente, é que o direito material trabalhista, no Brasil, tem um baixo índice de cumprimento espontâneo pelos destinatários de seus comandos normativos, muito menor do que qualquer ordenamento jurídico admite como tolerável (PIMENTA, 2004, p. 340).

\footnotetext{
5 A maior utilização das tutelas específica, de urgência e coletiva parece ser um importante - senão o mais importante - mecanismo para implementação dos paradigmas constitucionais de efetivação da tutela jurisdicional. A ampliação de tais mecanismos vem sendo possível a partir da releitura do papel do Poder Judiciário em uma perspectiva mais ativa - ativismo judicial - proporcionada pela superação dos paradigmas liberais e positivistas. Este aspecto será analisado mais a frente.

6 São três os tipos de litigiosidade enfrentados nos Tribunais brasileiros: a individual - ou de varejo - com situações

pontuais e isoladas; a coletiva, vinculada a reparação de direitos coletivos ou difusos; e a em massa - ou de alta intensidade (PIMENTA, 2012, p. 463-464).
} 
Esta cultura, infelizmente, parece estar arraigada em especial no Direito do Trabalho, talvez pelo caráter histórico da dicotomia capital e trabalho (e, portanto, do antagonismo dos interesses do patrão e do empregado). Viana (2012, p. 502) explica, com sua peculiar simplicidade, como as relações trabalhistas parecem partir de uma obrigação de nãocumprir (ao contrário do que se espera de uma relação contratual - reciprocidade e boa-fé):

É que, como sabemos, o Direito do Trabalho não se realiza tão facilmente como o Direito Civil. Enquanto o passageiro de um táxi nem sequer cogita em não pagar a corrida, o empresário tende a aplicar a lei como, quando, onde e quanto quer, e assim mesmo se quiser - governando-a tal como governa a Propriá força-trabalho.

Claro que inúmeros fatores contribuem para este aspecto (como a já mencionada dicotomia histórica da relação de emprego), mas, talvez um dos fatores mais importantes seja a tendência social de "coisificação" do trabalhador. A monetarização do trabalho (o trabalho visto especialmente sob uma ótica financeira) é içada pela tendência de se perceber o trabalhador apenas como uma engrenagem e, assim, totalmente descartável dentro do sistema de produção. Tal fato, facilitado pela ausência de proteção contra despedida arbitrária (pelo menos pela interpretação majoritária do art. $7^{\circ}$, inciso I, da $\mathrm{CR} / 88$ ), parece contribuir, e muito, para que se privilegiem as tutelas ressarcitórias ou subrogatórias às tutelas específicas! ${ }^{7}$

Daí uma crise se instaura em relação à efetividade da tutela jurisdicional trabalhista:

Hoje, o verdadeiro problema do Direito do Trabalho em nosso país é a falta de efetividade da tutela jurisdicional trabalhista (que torna extremamente vantajoso para grande número de empregadores, do ponto de vista econômico, descumprir as mais elementares obrigações trabalhistas), criando uma verdadeira cultura do inadimplemento, em verdadeira concorrência desleal com a parcela ainda significativa dos empregadores que cumprem rigorosamente suas obrigações trabalhistas, legais e convencionais (PIMENTA, 2004, p.

341 e 343$)$.

\footnotetext{
7 Muitas vezes essa tendência acaba por partir do próprio trabalhador que, por exemplo, prefere ser indenizado ao ser reintegrado. Não se costuma cogitar, no entanto, aos efeitos que a não reintegração pode gerar.
} 
A partir dessas premissas, algumas novas perspectivas se fazem necessárias para o resgate de um Direito Processual do Trabalho efetivo.

Primeiramente, deve-se tentar suplantar tendências reducionistas do privilégio por tutelas meramente ressarcitórias, retomando-se a preferência por tutelas específicas, especialmente porque essa preferência é tida, inclusive, como princípio especial do Direito Processual do Trabalho:

\begin{abstract}
São princípios fundamentais próprios do direito processual do trabalho: [...] princípio da prioridade da tutela específica sobre a tutela pelo equivalente monetário: a tutela específica tem prioridade sobre a ressarcitória pelo equivalente monetário. Esse princípio informa a autorização para que o juiz conceda medida liminar, em favor do trabalhador, nas reclamações trabalhistas que visem a tornar efeito a transferência ou reintegrar dirigente sindical afastado, suspendo ou dispensado (art. 659, IX e X, da CLT), que implica, inclusive, superação do dogma da impossibilidade de execução respaldada em cognição sumária ou da correlação necessária entre a execução forçada e a condenação (ALMEIDA,2006, p. 54-56).
\end{abstract}

Em segundo lugar, é bom destacar que para que se possa cogitar em tutela específica em amplo espectro (não apenas vinculada a uma obrigação pós-rescisão contratual, como é o caso das reintegrações), deve-se pensar em medidas capazes de resguardar os direitos do trabalhador imediatamente após a lesão, ou seja, na constância do contrato de trabalho.

De fato, dentro de um sistema de interpretação majoritariamente restritiva que privilegia a ausência de proteção contra despedida arbitrária - assim como a contagem de prazo prescricional ainda que no decorrer do contrato - é pouco provável se cogitar em ações de empregados. A maioria dos litigantes será - como o é - de desempregados ou ex-empregados.

Com isso, não há muito espaço para tutelas específicas e inibitórias efetivas se o reclamante, ao reclamar, já não mais se encontra no emprego. Sua reclamação, assim, apenas abarcará pedidos puramente pecuniários e/ou indenizações por danos e lesões pretéritas ${ }^{8}$.

Portanto, falar em tutela específica efetiva é falar, também, em tutelas metaindividuais e tutelas de urgência (cautelares ou antecipatórias) - para uma efetivação imediata e em larga escala.

\footnotetext{
$\overline{8}$ Parece muito pouco provável, caso não se mudem as perspectivas apontadas, que um empregado sem estabilidade, por exemplo, ajuíze uma ação em desfavor de seu atual empregador exigindo a marcação de suas férias (art. 137, §1 ${ }^{\circ}$, da CLT). In casu, a tutela específica quase sempre é trocada pela ressarcitória, pleiteada após o término do contrato de trabalho.
} 
Nessa perspectiva talvez resida o papel mais importante da coletivização da lide. Além de ter o propósito de desafogar o Poder Judiciário ${ }^{9}$, em especial como solução no combate aos litígios em massa, a tutela metaindividual tem o escopo de permitir que outra pessoa (que não o próprio do direito) possa ajuizar a ação e exigir a reparação coletiva do dano, anulando o risco e o temor pela perda do emprego por parte dos trabalhadores.

Assim, o ajuizamento de ações coletivas, em especial pelos sindicatos (substituição processual - art. $8^{\circ}$, III, da CR/88 - já tida como ampla, inclusive, pelo STF), deve ser vista não como uma legitimação extraordinária, mas como legitimação ordinária (natural no papel das organizações coletivas)!

Em terceiro lugar, uma última perspectiva pode ser somada às anteriores na busca de uma tutela jurisdicional mais efetiva. Trata-se do ativismo judicial que apresenta novas bases hermenêuticas ${ }^{10}$ para concretização dos direitos fundamentais, seja no âmbito processual, seja no âmbito material, a partir da superação do paradigma liberal do ponto de vista do Poder Judiciário $^{11}$.

De fato, a ruptura do liberalismo (Estado de Bem Estar Social) e do positivismo (póspositivismo), que compreendia o Direito com ciência de caráter puramente formal (escola exegética), fez com que os valores tomassem um papel central nas decisões judiciais (em busca da efetividade dos preceitos principiológicos fundamentais).

Com isso, o Poder Judiciário toma posição central na reconstrução e na efetivação do Direito (MURADAS, 2012, p. 26), com intepretações coerentes com o texto e o contexto posto (BROCHADO, 2006, p. 228) e expressando padrões éticos e de justiça em suas decisões.

O Poder Judiciário assume uma função politica ${ }^{12}$, incorporando as "vicissitudes do meio social e as conquistas das classes envolvidas, através da participação destas nos centros decisórios do poder" (TEODORO, 2012, p. 546). Há um alargamento da atuação judicial e o juiz adquire um papel de protagonista e corresponsável pela efetivação dos direitos.

\footnotetext{
9 Papel este que, de fato, é extremamente importante para a efetividade, pois uma justiça acessível, porém lenta, provocará quase que apenas vazios de tutela.

10 "As normas são o resultado de sua interpretação, que efetiva os direitos previstos abstratamente. Não há norma jurídica senão norma interpretada" (HÄBERLE, 1997, p. 14-15).

$11 \mathrm{O}$ magistrado deve ser estático, neutro; suas sentenças devem ser livres de qualquer juízo de valor; e seu papel se restringe à subsunção do fato à norma.

12 O pós-positivismo valoriza o "caráter normativo dos princípios jurídicos, o que enfraquece o reinado do Poder Legislativo [...]" (GARCIA, 2005, p. 135). Ademais, "a atuação criativa do juiz viabiliza o pleno exercício dos direitos fundamentais no contexto de um poder legislativo omisso e moroso". (TEODORO, 2012, p. 549).
} 
Assim, no Direito Processual do Trabalho, o novo papel assumido por um Juiz ativo e compromissado com uma nova compreensão hermenêutica da norma, pode permitir novos rumos e novas tendências interpretativas no aspecto da efetivação dos direitos fundamentais trabalhistas.

\section{ALgUNS CAMINHOS NA BUSCA DE UMA RAZOÁVEL DURAÇÃO DO PROCESSO}

Tendo como base os aspectos anteriormente ressaltados, tais como a fundamentabilidade do direito processual e a lógica interpretativa de uma tutela jurisdicional ampla, justa e efetiva ${ }^{13}$, não se pode negar que o direito a uma razoável duração do processo (inserido, a partir da Emenda Constitucional n. 45/2004, no eixo fundamental de garantias individuais - art. $5^{\circ}$, LXXVIII da CR/88) exige, em especial após a ruptura do positivismo jurídico (compreensão do Direito como uma ciência puramente formal - escola exegética), a busca por um sistema hermenêutico aberto e integrativo, não mais pautado nas clássicas barreiras da interpretação puramente gramatical.

E, a partir do momento que o Poder Judiciário toma posição central na reconstrução e na efetivação do Direito, assumindo sua função politica, o juiz passa a ser não mais um mero expectador, mas um protagonista direto e corresponsável pela efetivação dos direitos, em especial dos direitos fundamentais:

O Estado passa a aparecer, assim, como o devedor de postura ativa, no sentido de uma postura integral e global dos direitos fundamentais, deixando de ocupar na feliz formulação de Vieira de Andrade - a posição de "inimigo público", ou pelo menos, não mais de inimigo número um (ou único) da liberdade e dos direitos dos cidadãos, como poderíamos acrescentar (SARLET, 2000, p. 118).

\footnotetext{
13 “[...] o processo deve dispor de instrumentos de tutela adequados [...] a todos os direitos [...]; esses instrumentos devem ser praticamente utilizáveis [...] sejam quais forem os supostos titulares dos direitos [...]; impende assegurar condições propiciais à exata e completa reconstituição dos fatos relevantes [...]; [...] o resultado do processo há de ser tal

que assegure à parte vitoriosa o gozo pleno da específica utilidade a que faz jus segundo o ordenamento; [...] cumpre que se possa atingir semelhante resultado com o mínimo dispêndio de tempo e energias" (BARBOSA MOREIRA,1984a, p. 27-28).
} 
A fundamentabilidade do Direito Processual do Trabalho deve ser interpretada, inicialmente, de uma maneira peculiar em relação ao Direito Processual Comum. Meios processuais efetivos e céleres, na esfera trabalhista, viabilizam a entrega de uma prestação jurisdicional adequada e efetiva ao jurisdicionado, mas, principalmente, garantem a sobrevivência digna do trabalhador (visto pela ótica de que os créditos trabalhistas impregnados de caráter alimentar - servem-lhe à garantia do atendimento de suas necessidades vitais básicas - art. $7^{\circ}$, IV da $\mathrm{CR} / 88$ ). Ademais, a efetivação jurisdicional de um direito trabalhista lesado é, quase sempre, a efetivação de um direito social fundamental (caráter conferido pela própria Carta Magna em seu artigo $7^{\circ}$ ).

Assim, no Direito Processual do Trabalho, o novo papel assumido por um Juiz ativo e compromissado com uma nova compreensão hermenêutica da norma pode permitir rumos e tendências interpretativas importantes e essenciais para o aspecto da efetivação dos direitos fundamentais trabalhistas:

Os princípios constitucionais do processo e as novas técnicas dispostas nas ondas renovadoras da legislação processual devem, portanto, conduzir o intérprete a um olhar crítico e propositivo do Direito Processual do Trabalho, a fim de que, preenchendo as lacunas, quando necessário, restabeleça a isomorfia dos subsistemas integradores do Direito (fatos, valores e normas), em nome de uma ordem jurídica verdadeiramente justa (CHAVES, 2007, p. 94).

Dentro dessa perspectiva, duas questões podem ser destacadas: a primeira diz respeito à utilização irrestrita, sem os clássicos limites vinculados à tipologia legal, dos meios executivos disponibilizados ao juiz a partir da reforma processual de 1994 - não apenas na fase típica da execução, mas, também e principalmente, na fase de cognição (por meio das tutelas de urgência e de evidência). A segunda diz respeito à reinterpretação dos limites da subsidiariedade para fins de se suprir a natural incompletude do Direito Processual do Trabalho, além da clássica teoria das lacunas normativas, na busca de um processo mais célere e efetivo. 


\subsection{Repensando a Execução Trabalhista por Meio da Subsidiariedade Normativa}

Nas últimas décadas, as maiores discussões travadas em torno do direito processual (especialmente na teoria geral do processo) foram em relação a paradigmas do pensamento lógico- procedimental (superação do instrumentalismo; teoria neoinstitucionalista; etc..), questões muitas vezes mais acadêmicas que práticas (o que, por vezes, escondeu o principal enfoque do direito processual: a efetividade).

Nesse sentido, os embates se focaram muito na fase de cognição do processo: dentro da lógica da construção da sentença, pelas próprias partes, com as garantias constitucionais do contraditório e da ampla defesa. Pouco, no entanto, se pensou sobre execução (e, consequentemente, sobre os meios executivos disponibilizados ao juiz) ${ }^{14}$.

Com isso, percebe-se que o Direito Processual Civil, até o final do Século XX, não demonstrou muita preocupação (na seara legislativa, pelo menos) com a sua própria efetividade.

A título de exemplo, frisa-se no processo de execução. Sempre pareceu ilógico e contraproducente a existência da dualidade processo de conhecimento e processo de execução, sendo que, sem qualquer sentido prático, o credor, após consolidado seu título executivo, deveria instaurar novo procedimento (de execução) para satisfazer seus créditos. Não parece razoável a exigência de uma nova manifestação (por meio de uma nova petição inicial) para que se realize aquilo que, inicialmente (desde a fase cognitiva), se pretendia! Ademais, esgotada a cognição, a garantia de meios amplos de defesa ao devedor (salvo questões procedimentais, de nulidades e atinentes a cálculos) não parece fazer sentido.

O processo do trabalho, no entanto, e pelo contrário, surgiu como um grande avanço em relação à estrutura processual civil (seja em relação ao CPC de 1939, seja em relação ao CPC de 1973 - antes das suas últimas reformas). Tal avanço não se restringiu, é claro, apenas aos critérios da execução. Desde a distribuição da petição inicial (que já é naturalmente mais simples - art. 840 da CLT) até a fase de expropriação de bens, a CLT demonstrou uma grande sensibilidade à natureza alimentar dos créditos perseguidos pelo trabalhador e, assim, desenvolveu um procedimento simples, célere e, dentro dos limites até então concebidos, muito mais efetivo!

\footnotetext{
14 Não se nega que as garantias constitucionais do contraditório e da ampla defesa também estão presentes na fase de execução. No entanto, como nessa fase a intensidade e o enfoque de tais garantias são outros, os debates se concentraram na fase de conhecimento do processo.
} 
O processo do trabalho, no entanto, e pelo contrário, surgiu como um grande avanço em relação à estrutura processual civil (seja em relação ao CPC de 1939, seja em relação ao CPC de 1973 - antes das suas últimas reformas). Tal avanço não se restringiu, é claro, apenas aos critérios da execução. Desde a distribuição da petição inicial (que já é naturalmente mais simples - art. 840 da CLT) até a fase de expropriação de bens, a CLT demonstrou uma grande sensibilidade à natureza alimentar dos créditos perseguidos pelo trabalhador e, assim, desenvolveu um procedimento simples, célere e, dentro dos limites até então concebidos, muito mais efetivo!

Quanto à execução - ponto central desta análise - e a título exemplificativo:

i. Não há, na dinâmica celetista, um processo de execução, mas, apenas, uma fase de execução. Apesar de estruturada em um capítulo próprio, a execução nada mais é do que a continuação da cognição com o objetivo de satisfação do crédito ${ }^{15}$. As clássicas discussões processualistas ligadas à liquidação (se seria ligada à fase de conhecimento ou à execução) se esvaziam na esfera do Direito Processual do Trabalho.

ii. Além da manifestação dos próprios interessados, a fase de execução pode ser inaugurada de ofício, pelo próprio juiz, ou, ainda, pelo Ministério Público do Trabalho, nos casos de decisões de competência originaria dos Tribunais Regionais.

iii. Após a liquidação da sentença, o prazo para pagamento dos créditos ou para a garantia de juízo é de 48 horas contadas da citação.

iv. Os embargos do devedor, no prazo de cinco dias contados da ciência da garantia ou da penhora, têm matéria de defesa adstrita ao cumprimento da decisão ou do acordo, quitação ou prescrição da dívida ${ }^{16}$.

Tais aspectos exemplificativos, somados a todos os demais procedimentos celetistas, sempre tornaram o processo do trabalho mais simples, célere e eficaz, em comparação ao processo civil ${ }^{17}$.

\footnotetext{
${ }^{15}$ A satisfação do crédito sempre foi o objetivo da própria fase de conhecimento. Assim não há sentido em separar a satisfação (execução) da própria fase de conhecimento (processo sincrético).

${ }^{16}$ Nesse aspecto, no entanto, a jurisprudência vem admitindo a aplicação subsidiária do CPC (apesar de não existir omissão - frise-se) para possibilitar outros meios de defesa na fase de execução (especialmente em se tratando de execução de título executivo extrajudicial).

${ }^{17}$ Tal aspecto foi responsável, pelo menos em parte, para a discriminação do direito processual do trabalho pela maioria dos processualistas brasileiros. Mal sabiam que as reformas do CPC teriam a tendência de simplificação e desburocratização típicas do processo do trabalho...
} 
Dentro desta perspectiva é que foram concebidos os artigos 769 e 889 da CLT. Na época, já que o processo do trabalho consistia em relevante avanço em relação ao processo comum, o objetivo era de se evitar, ao máximo, a aplicação subsidiária do Direito Processual Civil. Com isso, evitar-se-ia que a dinâmica processual trabalhista pudesse ser maculada pela inefetividade quase que inerente à dinâmica processual comum:

O modelo construído até o momento partia da premissa de que o marco normativo trabalhista, embora incapaz de regular todas as questões processuais, apresentava-se mais dinâmico e efetivo que o marco normativo civil. Sendo assim, a aplicação subsidiária das normas de direito comum (CLT, arts. 769 e 889) deveria ocorrer apenas diante da efetiva omissão material da norma trabalhista (CORDEIRO, 2007, p. 26).

Portanto, a aplicação subsidiaria do CPC e da Lei de Execução Fiscal se davam apenas em casos de típica omissão da CLT. Destaca-se, inclusive, que a opção pela Lei de Execução Fiscal, em detrimento do CPC, mostra a preferência pela aplicação de uma estrutura legislativa tendenciosamente mais favorável ao credor (princípio da proteção), o que facilitaria a efetivação do direito material.

No entanto, desde seu surgimento, apesar de até então bastante avançado, o Direito Processual do Trabalho não sofreu mudanças significativas. Não houve, assim, uma efetiva reforma processual ${ }^{18}$.

Já o Direito Processual Civil, na última década do Século XX e na primeira década do Século XXI, passou por um período de grandes e significativas reformulações pautadas, em especial, no quesito da efetividade e celeridade do processo, já que "conseguiu se livrar de muitos dos entraves formais e anacrônicos que impediam a plenitude e a rapidez na prestação jurisdicional" (CORDEIRO, 2007, p. 27). Muitas dessas reformas, diga-se de passagem, parecem inspiradas no próprio Direito Processual do Trabalho.

A partir daí (avanço sistemático do Direito Processual Civil - em especial nos quesitos fundamentais da efetividade), percebe-se a necessidade de uma revisão interpretativa dos limites dos artigos 789 e 889 da CLT (consolidados em uma época de muito mais efetividade do Direito Processual do Trabalho). Faz-se de extrema relevância uma releitura dos critérios de subsidiariedade das fontes processuais em relação às lacunas normativas.

\footnotetext{
18 Não se nega a importante das últimas alterações em matéria de processo que foram, sim, significativas (extinção dos juízes classistas; instituição do procedimento sumaríssimo; criação de títulos executivos extrajudiciais; etc.). No entanto, a irrelevância de tais medidas é apenas cogitada na medida em que confrontadas com as reformas do Direito Processual Civil.
} 
De fato, novas bases interpretativas devem ser pensadas para a defesa da aplicação do instrumento processual mais efetivo e eficaz (teleologia esta vinculada à fundamentalidade não apenas do direito processual, como instrumento de efetivação dos direitos materiais, mas, também, com base no paradigma de um processo efetivo, no quesito celeridade, pautado no art. $5^{\circ}$, LXXVIII da CR/88):

A supremacia da Constituição, de suas normas e princípios, deve produzir na comunidade de intérpretes do Direito Processual Trabalhista o mesmo influxo que tem produzido nas outras dimensões da Ciência Jurídica. O Estado Constitucional demanda do interprete uma nova postura, sorvendo-se, inicialmente, do arcabouço constitucional para, somente em seguida, busca as demais instrumentalizações normativas infraconstitucionais.

O Direito Processual italiano admite a mesma possibilidade de superação de aspectos determinados do ordenamento processual infraconstitucional por força o influxo e supremacia de princípios de cariz constitucional, mormente diante do que consta da Constituição da República da Itália a respeito da prestação de tutela jurisdicional, que é assegurada através de um justo processo, incluindo-se nesse conceito sua duração adequada e razoável, tal qual o português e o espanhol. [...]

A partir dessa premissa constitucional, acentua Paulo Hoffman ser permitido aos juízes "interpretarem a lei de forma a considerar inconstitucionais quaisquer atividades inócuas e que representam atraso na atividade jurisdicional" [...] (CHAVES, 2007a, p. 144).

Dentro dessa premissa surge, assim, a denominada teoria das lacunas normativas, ontológicas e axiológicas:

As lacunas normativas estampam a ausência de norma sobre determinado caso, conceito que se aproxima das lacunas primarias de Engisch. As lacunas otológicas têm lugar mesmo quando presente uma norma jurídica a regular a situação ou caso concreto, desde que tal norma não estabeleça mais isomorfia ou correspondência com os fatos sociais, com o progresso técnico, que produziram o envelhecimento, "o ancilosamento da norma positiva" em questão.

As lacunas denominadas axiológicas também sucedem quando existe um dispositivo legal aplicável ao caso, mas, se aplicado, "produzirá uma solução insatisfatória ou injusta". Como o próprio nome sugere, as lacunas axiológicas estão intimamente relacionadas com a dimensão valorativa do fenômeno do Direito e tende a ocupar uma posição importante no atual cenário jurídico-processual, no qual desponta com vigor a força dos princípios, em especial os constitucionais, na tarefa de compreensão e aplicação do Direito no panorama do chamado pós-positivismo (CHAVES, 2007b, p. 6869).

Assim, em síntese, mais importante que a aplicação subsidiária ou supletiva por meio das simples lacunas normativas (ausência de previsão legal específica total ou parcial interpretação clássica do art. 769 da CLT c/c art. 15 do novo CPC - Lei n. 13.105 de 2015), surge a possiblidade de se preencher, por meio de fontes subsidiárias, lacunas ontológicas 
(a norma não é mais compatível com os fatos sociais e, assim, não é mais efetiva) e axiológicas (a norma leva a uma situação injusta ou incompatível com os valores de Justiça).

Essas novas possibilidades, juntamente com as clássicas interpretações ainda disponíveis, abrem caminho para a aplicação, sempre em prol da efetividade do Direito Processual Trabalhista, de regras do Direito Processual Comum mais condizentes com os novos parâmetros da interpretação constitucional:

Ora, se o texto constitucional vigente impõe a busca de um processo célere e mais efetivo, por que o juiz do trabalho deve recusar a aplicação de uma norma de processo civil mais dinâmica e flexível? Admitir a inflexibilidade do conteúdo formal do art. 769 da CLT, significa, nos dias atuais, negar a própria eficácia de um direito fundamental. Essa negação, muitas vezes, pode ser justificada pela observância cega do princípio da legalidade, consubstanciando-se na assertiva que a lei regula integralmente determinada matéria (CORDEIRO, 2007, p. 35).

É de ressaltar que as lacunas são da própria natureza do Direito Processual do Trabalho. Tal fato tem sido cogitado pela doutrina como princípio próprio do ramo, o que, portanto, reforçaria o argumento de aplicação subsidiária do direito processual comum em lacunas não apenas normativas - interpretação sistemática ou ampliativa (SCHIAVI, 2011, p. 110).

Partindo dessas premissas, a noção de incompletude do sistema processual trabalhista é a ele inerente. Assim, o direito processual se resguarda, sempre, a possibilidade de evoluir, independentemente de manifestação legislativa própria! Seja por suas próprias normas, seja pela integração normativa de outro sistema processual, o Direito Processual do Trabalho guarda a chave para manter-se sempre no limiar da efetividade ${ }^{19}$ :

[...] é possível afirmar que, no campo do Direito Processual do Trabalho, somente seria possível se falar em completude se se considerar, por ficção legal, a cláusula da subsidiariedade prevista no art. 769 da CLT como elemento integrativo formal do sistema. É que tal regra, de forma expressa, reconhece, em tese, a incompletude do ordenamento jurídico-processual do trabalho, ao permitir que o interprete lance mão do processo comum nos casos omissos (CHAVES, 2007b, p. 60).

\footnotetext{
19 Segundo Engisch (2001, p. 275), "a lacuna é uma incompletude insatisfatória do seio do todo jurídico". No entanto, talvez a existência das lacunas, no direito processual do trabalho, não demonstre sua incompletude ou deficiência. Pelo contrário. A presença de lacunas estratégicas pode significar um ordenamento propositalmente aberto na busca de uma integração normativa, ontológica ou axiológica sempre que algum ordenamento se identifique como mais efetivo que o seu próprio. Nesse sentido é que se deve pensar o sistema processual trabalhista
} 
Com isso, a aplicação plena de regras de efetividade do Direito Processual Comum (como, por exemplo, tutelas provisórias e tutela específica, respetivamente: artigos 294 a 311 e 497, 536, 537, 538 do novo CPC - Lei n. 13.105 de 2015) faz parte da integração natural de um direito processual que, como o trabalhista, evolui para garantir sempre os mecanismos mais céleres, simples e eficazes de cumprimento da sentença (especialmente pela natureza dos créditos envolvidos e da hipossuficiência inerente à relação trabalhista subordinada, objeto do direito material que se pretende fazer cumprir):

\footnotetext{
Ora, se o princípio é o da melhoria contínua da prestação jurisdicional, não se pode utilizar o argumento de que há previsão a respeito na CLT, como forma de rechaçar algum avanço que tenha havido neste sentido no processo comum, sob pena de negar a própria intenção do legislador ao fixar os critérios de aplicação subsidiária do processo civil. Notoriamente, o que se pretendeu (daí o aspecto teleológico da questão) foi impedir que a irrefletida e irrestrita aplicação das normas do processo civil evitasse a maior efetividade da prestação jurisdicional trabalhista que se buscava com a criação de um procedimento próprio na CLT (mais célere, mais simples, mais acessível). Trata-se, portanto, de uma regra de proteção, que se justifica historicamente. Não se pode, por óbvio, usar a regra de proteção do sistema como óbice ao seu avanço (SOUTO MAIOR, 2006, p. 920-921).
}

A partir dessa premissa, e reforçado pelo sistema sincrético processual adotado pela CLT (ausência de dualidade - processo de conhecimento e processos de execução) e, agora, também pelo CPC - reformas de 2005 e 2006 (Leis n. 11.187/05, 11.232/05, 11.276/05, 11.277/06 e 11.280/06) incorporadas no novo CPC - Lei n. 13.105 de 2015, parece inerente ao sistema processual trabalhista a adoção de meios executivos não apenas na fase formal da execução (execução definitiva ou provisória - após a sentença de primeiro grau - artigos 876 e 899 da CLT), mas ainda na fase de cognição, antes da própria sentença, por meio das tutelas de urgência (nos próprios moldes dos artigos 497 a 500 e 536 a 538 do novo $\mathrm{CPC}^{20}$ - art. 461 do antigo CPC - e do art. 765 da CLT):

\footnotetext{
20 Ora, se a tutela executiva se caracteriza "por estar orientada a suprir a não realização espontânea de determinada conduta, exigida para a satisfação de um direito subjetivo" (GUERRA, 1999, p. 23), então decerto que a satisfação da conduta pode e deve ser exigida, por todos os meios executivos disponíveis, tanto na fase de execução (com a decisão

definitiva já preferida - ainda que não transitada em julgado) como em sede de antecipação de tutela (a decisão interlocutória proferida, ao antecipar os efeitos da tutela, reveste-se de sua coercibilidade e, portanto, é passível de exigência por qualquer meio executivo).
} 
O novo art. 461 do Código de Processo Civil instituiu uma duplicidade de sistemas executivos, ou duas espécies de execução, a saber: a) a execução regida pelo Livro I do Código, que se realiza mediante a formal instauração de um processo autônomo, o processo executivo e (b) a execução imediata, feita em continuação ao processo de conhecimento e como fase deste, ulterior à sentença.

Por outro lado, valorizou-se a execução por coerção, consistente em pressionar a vontade do obrigado, para que cumpra (medidas de pressão psicológica). Chega-se com isso ao binômio proposto por Chiovenda, sendo lícito falar em medidas de coerção e medidas de sub-rogação, agora postas no mesmo nível perante o sistema brasileiro da execução civil (DINAMARCO, 2001b, p. 223).

Como se sabe, as medidas executivas disponíveis são classificadas em coercitivas (execução indireta) e subrrogatórias (execução direta). Nessas últimas:

[...] diante da recusa do devedor em realizar a conduta que satisfaça o direito consagrado no título executivo, o Estado-juiz pode substituir a atividade do devedor com sua própria atividade, proporcionando ao credor resultado idêntico ou equivalente (econômica e juridicamente) ao que ele obteria com a satisfação espontânea de seu direito pelo devedor (GUERRA, 1999, p. 24-25).

Neste sentido, a própria atuação do Poder Judiciário supre a inercia do devedor, independentemente de sua vontade. Já na execução indireta (ou por coerção), "a tutela realizase sempre com o cumprimento pelo próprio devedor da obrigação, embora induzido pela imposição de medias coercitivas" (GUERRA, 1999, p. 28). Assim, o devedor é pressionado, por medidas coercitivas, a cumprir a obrigação.

Ressalte-se que, inicialmente, o caminho mais eficaz parece ser o da execução indireta. Nesse caso, poderá o juiz, independentemente de restrições legais, utilizar-se quaisquer meios de coerção necessários (artigos 536, 537 e 538 do novo CPC - Lei n. 13.105 de 2015), de ofício ou a requerimento, para exigir que o próprio devedor cumpra a decisão, sempre com a prevalência pela tutela específica em detrimento da meramente ressarcitória (preferência legislativa especialmente configurada a partir da reforma processual de 1994):

É, todavia, fora de dúvida que prevalece nos principais ordenamentos jurídicos da atualidade, a tendência a eleger a tutela específica como a modalidade prioritária de proteção aos direitos subjetivos, relegando a tutela ressarcitória ou por equivalente a uma posição de mera subsidiariedade, para as hipóteses em que for prática e juridicamente impossível a tutela específica.

[...] a importância e a necessidade da execução indireta crescem significativamente em ordenamentos jurídicos onde esteja assegurada a prioridade lógico-jurídica da tutela específica, principalmente com relação às obrigações infungíveis (GUERRA, 1999, p. 41- 42 e 44). 
No entanto, não se pode privilegiar uma medida em detrimento de outra, pois o sistema de tutela executiva "não pode alcançar a completude requerida [...] se não forem atribuídos ao juiz poderes para determinar os meios executivos adequados, quer sub-rogatórios, quer coercitivos, sempre que aqueles previstos na lei se revelarem insuficientes" (GUERRA, 1999, p. 61).

Mas, por mais que se possa cogitar, inicialmente, que a ideia de uma execução direta (por subrrogação) fugiria à especificidade da tutela (pois não se trata do adimplemento da obrigação, mas, sim, do resultado do adimplemento da obrigação sem o concurso de vontade do devedor ${ }^{21}$ - seria apenas um resultado equivalente, portanto), certo é que a efetividade da tutela jurisdicional, como direito fundamental, exige meios concretos para garantir o adimplemento do direito subjetivo (pós-positivismo), se coadunando com uma coexistência pacífica e integrativa entre ambas as medidas disponíveis (coercitivas e subrrogatórias), ainda mais porque, no caso concreto, uma das medidas pode se tornar ineficiente. Neste sentido:

\footnotetext{
Com isso, pode garantir a preferência pela execução específica em ambas as hipóteses, conferindo amplos poderes ao juiz quer para ordenar medidas coercitivas e obter o cumprimento (induzido) do devedor, quer para determinar meios subrogatórios adequados a garantir, quando possível, a satisfação do credor sem a cooperação do devedor (GUERRA, 1999, p. 47-48).
}

Nessa perspectiva, a efetividade plena da tutela jurisdicional (que não se restringe, assim, apenas à fase de execução propriamente dita) depende da possibilidade de adoção de todos os meios executivos disponíveis (mais aqueles que o juiz entender necessários: art. 536, $\S 1^{\circ}$ do novo CPC - Lei n. 13.105 de 2015) em todas as fases do processo (inclusive na fase de cognição - tutelas de urgência e de evidência).

Dessa forma, "descumprido o preceito da sentença ou de sua antecipação, passa-se às medidas executivas lato sensu, no mesmo processo de conhecimento já instaurado" (GRINOVER, 1996, p. 260). Daí se concluir que o direito processual reconheceu "a existência de sentenças condenatórias imediatamente executivas ou, em outras palavras, de sentenças executivas lato sensu" (GRINOVER, 1996, p. 260).

${ }^{21}$ Essa concepção foi defendida por Francesco Carnelutti. 
A partir disso, tem-se que a processualista comum, estampada especialmente nos artigos 497 a 500 e 536 a 538 do novo CPC - Lei n. 13.105 de 2015 (aplicável à sistemática processual trabalhista) impõe uma visão do processo como uma unidade, sem divisões em fases que poderiam macular a efetividade da tutela jurisdicional, não importando o momento ou a instância (interpretação conforme a Constituição). Não é outro o caminho que seguem as jurisprudências estrangeiras como, a título de exemplo, Itália e França:

Em ambos os países, a concessão da tutela de urgência vai tendendo a assegurar ao interessado, de direito ou ao menos de fato, o gozo definitivo do beneficio pleiteado. Isto é: a solução em principio simplesmente provisória do litigio adquire estabilidade equiparável àquela que teria a solução final. O fenômeno tem-se imposto na prática, não obstante as rugas de preocupação, quando não de franca desaprovação, que pode e costuma provocar num setor da doutrina. [...] tanto na Itália quanto na França, um dos tópicos comuns na casuística das medidas em foco é o de demissões supostamente ilegítimas de empregados, que vêem reintegrados amiúde por força de provvedimenti d'urgenza ou de ordonnances de référé. (BARBOSA MOREIRA, 1984b, p. 99). 


\section{CONCLUSÃO}

A partir da década 70 deu-se início, no ocidente, a uma série de reformas processuais com a tendência de efetivação da tutela jurisdicional. No Brasil, a reforma do judiciário (Emenda Constitucional n. 45/2004) é que aproximou tais anseios à realidade, reforçando e resguardando a efetividade (especialmente pela celeridade) e a democratização do processo (ampliando-se o acesso à justiça e criando transparência e controle democrático da atividade jurisdicional). Portanto, uma tutela jurisdicional efetiva, do ponto de vista constitucional, parece ser aquela que tende a implementar as grandes questões postas acima.

Como o Direito Processual do Trabalho é um direito fundamental e, ainda, como a tutela jurisdicional é fundamental para a concretização das normas trabalhistas - sociais por natureza (garantem a sobrevivência digna do trabalhador, servindo-lhe à garantia do atendimento de suas necessidades vitais básicas), algumas novas perspectivas se fazem necessárias para o resgate de sua efetividade.

Além da tentativa de se reduzir o privilégio por tutelas meramente ressarcitórias e individuais, por exemplo, uma das perspectivas em destaque é reinterpretação dos limites da subsidiariedade para fins de se suprir a natural incompletude do Direito Processual do Trabalho, na busca de um processo mais célere e efetivo.

Assim, seria possível cogitar na utilização irrestrita dos meios executivos disponibilizados ao juiz - não apenas na fase típica da execução, mas, também, na fase de cognição - e na construção de um Direito Processual do Trabalho sincrético, espelhado nas reformas de 2005 e 2006 do antigo Código de Processo Civil (Leis n. 11.187/05, 11.232/05, 11.276/05, 11.277/06 e 11.280/06) que culminaram com a nova estrutura do Direito Processual Civil - Lei n. 13.015, de 2015 (novo CPC).

Com isso, a tutela jurisdicional trabalhista poderia alcançar um novo patamar de efetividade e de celeridade, permitindo que a duração razoável do processo incluísse não apenas a solução integral do mérito, mas também - e principalmente - toda a atividade satisfativa. 


\section{REFERÊNCIAS}

ALMEIDA, Cléber Lúcio. Direito processual do trabalho. Belo Horizonte: Del Rey, 2006.

BARBOSA MOREIRA, José Carlos. Notas sobre o problema da "efetividade" do processo. In: Temas de direito processual, terceira série. São Paulo: Saraiva, 1984a.

BARBOSA MOREIRA, José Carlos. Tutela de urgência e efetividade do direito. In: Temas de direito processual, oitava série. São Paulo: Saraiva, 1984b.

BROCHADO, Mariá. Direito e ética: a eticidade do fenômeno jurídico. São Paulo: Landy, 2006. CHAVES, Luciano Athayde. As reformas processuais e o processo do trabalho. Revista TST, Brasília, vol. 73, n. 1, jan/mar 2007a.

CHAVES, Luciano Athayde. As lacunas no direito processual do trabalho. In: CHAVES, Luciano Athayde. (Org.). Direito processual do trabalho: reforma e efetividade. São Paulo: LTR, 2007b.

CORDEIRO, Wolney de Macedo. Da releitura do método de aplicação subsidiária das normas de direito processual comum ao processo do trabalho. In: CHAVES, Luciano Athayde. (Org.). Direito processual do trabalho: reforma e efetividade. São Paulo: LTR, 2007.

DINAMARCO, Cândido Rangel. Instituições de direito processual civil. São Paulo: Malheiros, 2001a, v. I.

DINAMARCO. Cândido Rangel. A reforma da reforma. $4^{\text {a }}$ ed. rev. atual. São Paulo: Editora Malheiros, 2001b.

ENGISCH, Karl. Introdução ao pensamento jurídico. Lisboa: Fundação Calouste Gulbenkian. Tradução de J. Baptista Machado, 2001.

GARCIA, Emerson. Principio da separação dos poderes: os órgãos jurisdicionais e a concreção dos direitos sociais. Revista da EMERJ, Rio de Janeiro, n. 30, p. 129-167, 2005.

GONÇALVES, Aroldo Plínio. Técnica processual e teoria do processo. Rio de Janeiro: Aide, 1992.

GRINOVER, Ada Pellegrini. Tutela jurisdicional nas obrigações de fazer e não fazer. In: Reforma do Código de Processo Civil. São Paulo: Saraiva, 1996.

GUERRA, Marcelo Lima. Execução indireta. São Paulo: Revista dos Tribunais, 1999.

HÄBERLE, Peter. Hermenêutica constitucional - a sociedade aberta dos intérpretes da Constituição: contribuição para a interpretação pluralista e procedimental da Constituição. Tradução: Gilmar Ferreira Mendes. Porto Alegre: Sergio Antônio Fabris, 1997.

MARINONI, Luiz Guilherme. Técnica processual e tutela dos direitos. São Paulo: RT, 2004. 
MARINONI, Luiz Guilherme. Teoria geral do processo, 3 ed., São Paulo: RT, 2008, v. I.

MURADAS, Daniela. Influxos legais, jurisprudenciais e o princípio da vedação do retrocesso social. In: VIANA, Márcio Túlio et al. (Coords.). O que há de novo em direito do trabalho, 2 ed. São Paulo: LTr, 2012.

PIMENTA, José Roberto Freire. Súmulas vinculantes: uma reapreciação critica. In: VIANA, Márcio Túlio et al. (Coords.). O que há de novo em direito do trabalho, 2 ed. São Paulo: LTr, 2012.

PIMENTA, José Roberto Freire. Tutelas de urgência no processo do trabalho: o potencial transformador das relações trabalhistas nas reformas do CPC brasileiro. In: PIMENTA, José Roberto Freire et al. (Coords.). Direito do trabalho: evolução, crise, perspectivas. São Paulo: LTr, 2004.

PROTO PISANI, Andrea. Lezioni de diritto processuale, apud ALMEIDA, Cléber Lúcio. Direito processual do trabalho. Belo Horizonte: Del Rey, 2006.

REALE, Miguel. Filosofia do direito, 19 ed. Sao Paulo: Saraiva, 2002.

SARLET, Ingo Wolfgang. Direitos Fundamentais e Direito Privado: algumas considerações em torno da vinculação dos particulares aos direitos fundamentais. In: SARLET, Ingo Wolfgang (Org.). A Constituição Concretizada - Construindo pontes com o público e o privado. 1ed.Porto Alegre: Livraria do Advogado, 2000.

SCHIAVI, Mauro. Manual de direito processual do trabalho, 4 ed. São Paulo: LTr, 2011.

SOUTO MAIOR, Jorge Luiz. Reflexos das alterações do Código de Processo Civil no processo do trabalho. Revista LTr, São Paulo, v. 70, n. 8, 2006.

TEODORO, Maria Cecília Máximo. Ativismo judicial: entre o mito da irresponsabilidade e o caminho da efetividade. In: VIANA, Márcio Túlio et al. (Coords.). O que há de novo em direito do trabalho, 2 ed. São Paulo: LTr, 2012.

VIANA, Márcio Túlio. As várias faces da terceirização. In: VIANA, Márcio Túlio et al. (Coords.). O que há de novo em direito do trabalho, 2 ed. São Paulo: LTr, 2012. 